\title{
REFLEKSI PEMBATASAN USIA PERKAWINAN DALAM UNDANG-UNDANG NOMOR 1 TAHUN 1974 TENTANG PERKAWINAN MENURUT FILSAFAT HUKUM KELUARGA ISLAM \\ Oleh: Moch. Nurcholis *
}

\begin{abstract}
To realize such an ideal family aspired (based on) Qur'an, the fulfillment of the element Sakinah (serenity), Mawaddah (compassion) and Rahmah (compassion), presumably the presence of Act No. 1 of 1974 About Marriage (UUP) has a very significant role in the country of Indonesia that the majority of the population converted to Islam (are muslim). One form of the rules, the UUP to apply the principles of mental and physical readiness through a specific age restriction for the bride who wants to make the fabric of marriage (to get married). Then how (does) UUP set age restrictions on marriage? and philosophical value of what (what philosophical value) can be captured by ( throught) the philosophy of Islamic family law?
\end{abstract}

To answer the above problems, this study used a descriptive-analytic method. The required data in the study and presented in ways that are collected for later analysis. ( the required data are collected and presented in particular ways to be analyzed). While the approach is

* Fakultas Syari'ah Institut Agama Islam Bani Fatah Jombang. email: cholis1986@gmail.com 
used to examine the normative and philosophical approach. Normative approach is needed to decipher the law setting an age limit of marriage, while the philosophical approach used wherever possible in order to uncover the philosophical values contained in the regulation of marriage age limit.

From the research that has been conducted resulting (wes can discover )two things. First, (the) setting the marriage age restrictions as set forth in Law No. 1 of 1974 of Article 7, paragraph (1) shall be conducted as a setting for the realization of the ideals of marriage as set forth in Article 1 UUP. Restricted marriage age is an important opportunity for exceptions as set forth in UUP Article 7 paragraph (2). Second, the philosophical value of the preparation of the marriage age restriction rules in the UUP can be reviewed through the ontological aspects, epistemological and axiological. According to the philosophy of family law, marriage age restriction as Philosophy tashri terkatagori (classified as philosophy of 'tashri'). especially those problems Maqasid al-Ahkam (the objectives of Islamic law) in the form of compliance (accompishing) maslahat and resist damage.

Keywords: Reflection, the Marriage Age Restrictions, Philosophy of Islamic Family Law

\section{Pendahuluan}

Hukum Islam disusun mengacu pada pandangan hukum yang bersifat teleologis. Artinya, hukum Islam diwujudkan untuk menghasilkan suatu tujuan tertentu. Keseluruhan dari tujuan hukum Islam yang disampaikan secara global oleh Al-Qur'an dan dirinci oleh al-Sunnah, menurut al-Shāțibi keseluruhannya kembali kepada maslahah yang terakumulasi menjadi tiga kelompok besar yakni pemenuhan kebutuhan bersifat daruri (primer), hajji (sekunder) dan tahsin̄i (tersier). Dalam perkembangannya kebutuhan darūri terbagi atas 5 (lima) hal yang populer dengan sebutan al-darürat al-khams, meliputi perlindungan terhadap agama, jiwa, akal, harta dan 
keturunan. $^{2}$ Manifestasi perlindungan terhadap keturunan dalam hukum Islam adalah dilarangnya perzinahan. Dalam kitab suci AlQur' an surat al-Isra' disebutkan:

"Dan janganlah kamu mendekati zina; sesungguhnya zina itu adalah suatu perbuatan yang keji dan suatu jalan yang buruk." 3

Ayat di atas menjelaskan larangan terhadap perbuatan-perbuatan yang merupakan pendahuluan zina, seperti berciuman, berpelukan dan lain sebagainya. Larangan melakukan pendahuluan zina merupakan langkah preventif agar manusia tidak sampai jatuh pada perzinahan. Jika melakukan pendahuluannya dilarang, lebih-lebih pada perbuatan perzinahannya. Pensyariatan larangan perzinahan bukan dimaksudkan untuk menghalangi manusia bereproduksi dan menyalurkan kebutuhan biologisnya. Namun agar terhindar dari dampak negatif yang ditimbulkannya. Di antara dampak perbuatan zina adalah terputusnya garis keteurunan, penyebaran penyakit, timbulnya bentuk pelanggaran yang lain semacam pembunuhan, runtuhnya keutuhan rumah tangga, dan adanya hubungan biologis yang bersifat sementara seperti halnya binatang. ${ }^{4}$

Perlindungan terhadap keturunan disamping melalui larangan perzinahan seperti yang tersebut di atas, dengan tujuan perlindungan yang sama, hukum Islam mensyariatkan adanya perkawinan. ${ }^{5}$ Agar terhindar dari dampak negatif hasil dari perzinahan, maka diperlukan adanya pengaturan tentang ikatan suami-isteri. Pada posisi inilah shar'̄'ah perkawinan menempati kedudukan sebagai hăjat yang merupakan penyempurna keterjaminan pemenuhan darürat. $^{6}$

Shari'ah perkawinan selain ditujukan untuk reproduksi dan pemenuhan kebutuhan biologis, juga dimaksudkan untuk menciptakan situasi psikologis yang sakinah (ketenteraman), mawaddah (rasa kasih) dan rahmah (rasa sayang). Firman Allah SWT:

"Allah menjadikan bagi kamu pasangan-pasangan dari kalanganmu sendiri dan menjadikan bagimu dari pasangan-pasanganmu itu

\footnotetext{
2 Muhammad Ramaḍān al-Būṭì, Dawābit al-Mậlahah (Beirut: Mu'assasat alRisālah, 2001), 110.

3 Al-Qur'an, 17: 23.

${ }^{4}$ Sayyid Sābiq, Fiqh al-Sunnah, Vol. 2 (Beirut: Dār al-Fikr, 1990), 341.

${ }^{5}$ Al-Buți, Dawābit......, 110.

${ }^{6}$ Hammādì al-'Ubaidi, Al-Shatibī wa Maqāsid al-Shariah (Beirut: Dār Qutaybah, $1992), 122$.
} 
anak-anak dan cucu-cucu dan memberimu rizki dari yang baikbaik. Maka mengapakah mereka beriman kepada yang batil dan mengingkari nikmat Allah?" 7

Dan di antara tanda-tanda kebesaran-Nya adalah bahwa menjadikan untukmu pasangan-pasangan dari kalanganmu sendiri supaya kamu cenderung dan merasa tenteram terhadapnya (sakinah) dan dijalaninya rasa kasih (mawaddah) dan sayang diantaramu (rahmah). Sesungguhnya pada yang demikian itu terdapat tandatanda bagi kaum yang berpikir. ${ }^{8}$

Ayat di atas, memberi gambaran bahwa keluarga ideal dalam Islam adalah jalinan secara terpadu antara unsur sakinah, mawaddah dan rahmah. Terdiri dari unsur suami yang jujur dan tulus, ayah yang penuh rasa kasih sayang dan ramah, ibu yang lemah lembut dan berperasaan halus, putra-putri yang patuh dan taat serta kerabat yang saling membina silaturrahim dan tolong menolong. ${ }^{9}$

Tuhan menganjurkan agar kehidupan keluarga menjadi bahan pemikiran setiap manusia dan hendaknya darinya dapat ditarik pelajaran berharga. Keluarga adalah umat kecil yang memiliki pimpinan dan anggota, mempunyai pembagian tugas dan kerja, serta hak dan kewajiban bagi masing-masing anggotanya. Kitab Suci menamakan satu komunitas dengan kata ummah, demikian pula menamakan ibu yang melahirkan anak keturunan dengan kata umm.

Lalu bagaimanakah cara mewujudkan keluarga ideal yang telah disebutkan oleh Al-Qur'an tersebut pada zaman yang ditandai dengan munculnya paham kenisbian yang berkaitan dengan nilai-nilai hidup dan keluarga, ketika sekat pergaulan antara pemuda dan pemudi sudah sebegitu tipisnya, dan ketika nilai-nilai agama hanya difokuskan kepada urusan ritual-ritual semata? Berkaitan dengan pertanyaan tersebut, perlu kiranya diungkapkan bahawa di Jepang terdapat kecenderungan perubahan sosial bahwa keluarga tidak didefinisikan sebagai kehidupan rumah tangga yang terdiri dari ayah, ibu, anak-anak dan orang-orang yang memiliki hubungan sedarah atau semenda, namun di Jepang seseorang mencukupkannya dengan dirinya sendiri dan pembantu (pekerja) rumah tangga yang membantu kehidupannya.

\footnotetext{
${ }^{7}$ Al-Qur'an, 16: 72.

${ }^{8}$ Al-Qur'an, 30: 21.

${ }^{9}$ Huzaimah Tahido Yanggo, Masail Fiqhiyah, Kajian Hukum Islam Kontemporer (Bandung: Angkasa, 2005), 134.
} 
Demikianpula yang terjadi di berbagai belahan bumi yang menjalani kehidupan keluarga namun tidak didasari atas dasar pernikahan. Jika ditelusuri, salah satu penyebabnya adalah tidak terpenuhinya tiga unsur pemebentukan keluarga sebagaimana yang telah digariskan oleh kitab suci, yakni tiadanya rasa ketenteraman, rasa kasih dan rasa sayang, sehingga pembentu-kan keluarga dinilai sebagai hanya penyaluran hasrat seksual semata dan pemenuhan kebutuhan fisik.

Untuk mewujudkan keluarga ideal seperti yang dicita-citakan AlQur'an, kiranya kehadiran Undang-Undang Nomor 1 Tahun 1974 Tentang Perkawinan (UUP) memiliki peran yang sangat signifikan di negara Indonesia yang mayoritas penduduknya memeluk agama Islam ini. Salah satu bentuk aturannya, UUP menerapkan asas kesiapan mental dan fisik melalui pembatasan usia tertentu bagi calon mempelai yang hendak melakukan jalinan perkawinan. Lalu bagaimanakah UUP mengatur pembatasan usia perkawinan? dan nilai filosofis apa yang dapat ditangkap menurut filsafat hukum keluarga Islam?

Penelitian ini menggunakan metode deskriptif-analitik. Data yang dibutuhkan dalam penelitian dikumpulkan dan dipaparkan sedimikian rupa untuk kemudian dianalisis. Sedangkan pendekatan yang digunakan untuk meneliti adalah pendekatan normatif dan filosofis. Pendekatan normatif dibutuhkan untuk menguraikan ketentuan hukum pengaturan batasan usia perkawinan, sedangkan pendekatan filosofis digunakan guna mengungkap sedapat mungkin nilai-nilai filosofis yang terkandung dalam pengaturan batasan usia perkawinan.

\section{Pembahasan}

1. Pembatasan Usia Perkawinan dalam Undang-Undang Nomor 1 Tahun 1974

Perkawinan dalam Undang-Undang Nomor 1 Tahun 1974 Pasal 1 disebutkan sebagai:

Ikatan lahir batin antara seorang pria dengan seorang wanita sebagai suami isteri dengan tujuan membentuk keluarga (rumah tangga) yang bahagia dan kekal berdasarkan Ketuhanan Yang Maha Esa. ${ }^{10}$

${ }^{10}$ Undang-Undang Nomor 1 Tahun 1974 Tentang Perkawinan Pasal 1. 
Dari definisi diketahui bahwa perkawinan menurut UUP tidak hanya terbatas pada masalah hubungan perdata secara lahir saja, tetapi juga merupakan hubungan spritual yang bersifat transedental. Oleh karena itu, ketentuan ini sangat berbeda dengan apa yang diatur oleh Burgerlijk Wetboek (KUHPerdata) yang menyatakan bahwa Undang-Undang memandang soal perkawinan hanya dalam hubungan-hubungan perdata (Pasal 26 KUHPerdata).

Kebenaran koherensi (kebenaran atas dasar konsistensi argumen) Pasal 1 tersebut begitu jelas teramati ketika dalam Pasal 2 ayat (1) disebutkan:

Perkawinan adalah sah, apabila dilakukan menurut hukum masing-masing agamanya dan kepercayaannya itu. ${ }^{11}$

Selain adanya sisi sakralitas dalam perkawinan, UUP menyebutkan bahwa perkawinan bertujuan untuk menciptakan keluarga yang bahagia dan kekal. Untuk mewujudkannya, UUP dalam Pasal 31 UUP mengatur tentang hak dan kewajiban yang harus dijalankan oleh masing-masing suami dan isteri. Hak dan kedudukan isteri adalah seimbang dengan hak dan kedudukan suami dalam kehidupan rumah tangga dan pergaulan hidup bersama dalam masyarakat. Masing-masing pihak berhak untuk melakukan perbuatan hukum.

Selain mengatur tentang hak dan tanggung jawab suami dan isteri, untuk mewujudkan keluarga yang bahagia dan kekal UUP juga menetapkan kriteria kelayakan bagi yang akan melaksanakan perkawinan. Penetapan kriteria didasarkan pada usia calon pengantin. Langkah demikian kiranya perlu dilakukan agar ketika sudah berkeluarga tidak terjadi perceraian dan ketidak harmonisan oleh sebab belum adanya kedewasaan dan kematangan secara mental untuk mejalani perkawinan dan menyelesaikan problem dalam berumah tangga yang muncul. Dalam UUP Pasal 7 ayat (1) disebutkan:

Perkawinan hanya diizinkan jika pihak pria sudah mencapai umur 19 (sembilan belas) tahun dan pihak wanita sudah mencapai umur 16 (enam belas) tahun. ${ }^{12}$

Berkaitan dalam kadaan tertentu diperlukan pengecualiaan tentang batasan usia, maka dalam ayat (2) disebutkan:

${ }^{11}$ Undang-Undang Nomor 1 Tahun 1974 Tentang Perkawinan Pasal 2 ayat (1).

12 Undang-Undang Nomor 1 Tahun 1974 Tentang Perkawinan Pasal 7 ayat (1). 
Dalam hal penyimpangan terhadap ayat (1) pasal ini dapat meminta dispensasi kepada Pengadilan atau pejabat lain yang ditunjuk oleh kedua orang tua pihak pria atau pun pihak Wanita. $^{13}$

Batasan umur yang termuat dalam UU perkawinan sebenarnya masih belum terlalu tinggi dibandingkan dengan beberapa negara lainnya di dunia. Al-Jazair misalnya membatasi umur untuk melangsungkan pernikahan itu, laki-lakinya 21 tahun dan yang perempuan 18 tahun. Demikian juga dengan Bangladesh 21 tahun untuk laki-laki dan 18 tahun untuk perempuan. Memang ada juga beberapa negara yang mematok umur tersebut sangat rendah. Yaman Utara misalnya membatasi usia perkawinan tersebut pada umur 15 tahun baik laki-laki maupun perempuan. Malaysia membatasi usia perkawinannya, laki-laki berumur 18 tahun dan yang perempuan 16 tahun. Dan rata-rata negara di dunia membatasi usia perkawinan itu laki-laki 18 tahun dan wanitanya berkisar 15 dan 16 tahun. $^{14}$

Pengaturan tentang usia ini sebenarnya sesuai dengan prinsip perkawinan yang menyatakan bahwa calon suami dan isteri harus telah masak jiwa dan raganya agar tujuan perkawinan untuk menciptakan keluarga yang kekal dan bahagia secara baik tanpa berakhir dengan perceraian dan mendapat keturunan yang baik dan sehat dapat diwujudkan. ${ }^{15}$ Usia kedewasaan dengan demikian menjadi keharusan yang harus terpenuhi dalam menjalin hubungan keluarga.

Sebenarnya, hukum yang berlaku di Indonesia menetapkan beragam usia kedewasaan. Hukum pidana menetapkan usia 16 Tahun, ketentuan Pemilu menetapkan usia 17 Tahun, sedangkan Hukum Perdata menetapkan usia 21 tahun. Dalam UUP pasal 6 ayat (2) disebutkan:

Untuk melangsungkan perkawinan seorang yang belum mencapai usia 21 (dua puluh satu) tahun harus mendapat izin kedua orang tua. ${ }^{16}$

\footnotetext{
${ }^{13}$ Undang-Undang Nomor 1 Tahun 1974 Tentang Perkawinan Pasal 7 ayat (2).

14 Amiur Nuruddin dan Azhari Akamal Taringan, Hukum Perdata Islam di Indonesia (Jakarta: Prenada Media, 2004), 69.

${ }^{15}$ Ibid.

${ }^{16}$ Undang-Undang Nomor 1 Tahun 1974 Tentang Perkawinan Pasal 6 ayat (2).
} 
Dalam kesejarahan pembentukan UUP dikatakan bahwa yang menjadi pertimbangan batasan usia kawin adalah kematangan secara biologis seseorang. Pembatasan usia perkawinan, menurut Dyah Saptaningrum sebagaimana diungkap kembali oleh Ratna Bantara Munti, pada saat itu dimaksudkan untuk mengantisipasi maraknya perkawinan anak-anak yang isunya bergulir sejak tahun 1920-an. ${ }^{17}$

Sedangkan dalam hukum Islam, sebagaimana yang pendapat mayoritas ulama, tidak ada pembatasan usia perkawinan secara tertentu. Tiadanya batasan ini disebabkan oleh tiadanya ketentuan dari Al-Qur'an dan al-Sunnah yang menetapkan batasan itu. Landasan yuridis yang digunakan sebagai dasar pernikahan di bawah usia perkawinan adalah perilaku keagamaan (sunnah fi'liyyah) Nabi Muhammad SAW. sewaktu menikahi 'Aishah yang pada saat itu masih gadis belia berusia 6 tahun. Kisah pernikahan ini terekam dengan sanad sahih dalam salah satu kitab terbaik dalam kajian hadith, dan bahkan yang bertindak sebagai perawi adalah sang mempelai perempuan sendiri, 'Aishah ra.;

\section{"Nabi menikahiku pada saat usiaku 6 tahun, dan hidup bersamaku pada usia 9 tahun." 18}

Dalam kajian sejarah, perilaku pernikahan semacam di atas juga merupakan salah satu tradisi di kalangan bangsa Arab, baik sebelum ataupun sesudah kerasulan Muhammad SAW. Salah satu contohnya adalah pernikahan kakek Nabi, 'Abd al-Mutallib yang sudah berusia udzur dengan Hallah yang merupakan kakak sepupu Aminah pada hari yang sama dengan pernikahan 'Abdullāh, anak bungsu 'Abd al-Mutallib, dengan teman Hallah, yakni Aminah binti Wahāà. ${ }^{19}$ Dan kelak 'Umar bin Khațtāo juga menikah dengan putri 'A li bin Abī Țālib yang bernama Ummu Kulthum, sedangkan usia 'Umar pada saat itu lebih tua daripada 'Ali. Diriwayatkan pula bahwa 'Umar pernah mengusulkan kepada Abū Bakr Untuk menikahi putrinya, Hafșah yang masih muda. Perbedaan umur di atara keduanya sama dengan perbedaan umur antara Nabi SAW.

\footnotetext{
${ }^{17}$ Ratna Batara Munti dan Hindun Anisah, Posisi Perempuan Dalam Hukum Islam di Indonesia (Jakarta: LBH-APIK, 2005), 53.

${ }^{18}$ Muslim b. Hajjaj, Sāhịh Muslim (Beirut: Dār al-Kutub al-'Ilmiyah, 2006), indeks 14222, j. 9, 176.

19 'Aisyah Binti Syathi', Nisā' al-Nabī, terj. (Bandung: Pustaka Hidayah, 2004), 121.
} 
dengan 'Aishah. ${ }^{20}$ Namun demikian, hal yang perlu digaris bawahi dari kenyataan sejarah ini adalah pada dasarnya ketiadaan batasan minimal usia dalam pernikahan pada saat itu dikarenakan tujuan utama dari perkawinan lebih dimaksudkan untuk menjalin hubungan musāharah yang sangat bermanfaat untuk menjalin hubungan guna penyebaran agama, bukan untuk penyaluran hasrat biologis semata. $^{21}$

Bertolak dari pandangan di atas, Ibn Shubrumah, Abū Bakr alAșam dan Uthman al-Batti memiliki pandangan yang berbeda dengan mayoritas ulama. Mereka berpandangan bahwa calon mempelai, baik laki-laki atau pun perempuan di bawah umur tidak sah untuk dikawinkan. Keduanya hanya boleh dinikahkan setelah mencapai usia bāligh (sudah mencapai usia dewasa) dan melalui adanya persetujuan yang disampaikan secara eksplisit. ${ }^{22}$ Dasar yang dibuat pijakan pendapat hukum adalah firman Allah SWT.:

"Dan ujilah anak yatim itu sampai mereka cukup umur untuk menikah." 23

Masih menurut pandangan kelompok yang mensyaratkan adanya batasan usia perkawinan, disebutkan bahwa jika anak-anak belia tersebut boleh untuk dinikahkan sebelum bäligh, maka apa jadinya arti ayat ini? Selain itu, anak-anak yang masih belia sebenarnya belum membutuhkan untuk menikah. Selanjutnya, mengenai kasus perkawinan Nabi Muhammad SAW. dengan 'Aishah yang masih berusia 6 tahun, Ibn Shubrumah berpendapat bahwa hal itu merupakan previlige (hak istimewa) bagi Nabi sendiri yang tidak bisa diberlakukan bagi umatnya. ${ }^{24}$

Jika mengamati pendapat di atas, kiranya kita juga perlu melihat sabda Nabi SAW. yang menganjurkan seorang pemuda untuk segera menikah. Nabi SAW bersabda:

“Wahai para pemuda (al-shabāb), barangsiapa di antara kalian mampu untuk jima' (sebab mempunyai biaya pernikahan),

\footnotetext{
${ }^{20}$ Ibnu Qudamah, Al-Mughnī (Beirut: Dār al-Fikr, 1984), j. 9, 487.

21 Amir Syarifuddin, Hukum Perkawinan Islam di Indonesia (Jakarta: Kencana, 2007), 67.

22 Ibid.

${ }^{23}$ Al-Qur'an, 4: 6.

${ }^{24}$ Ibnu Ḥazm, Al-Muhalla, CD al-Maktabah al-Shāmilah, Vol. 9, 459.
} 
maka nikahlah. Dan siapa tidak mampu maka, hendaknya ia berpuasa sebab puasa baginya adalah sebuah perisai." 25

Penggunaan redaksi al-shabāb hadith tersebut berartikan orang yang telah mencapai usia bāligh dan belum mencapai umur 30 tahun. Hal ini mengindikasikan adanya pertimbangan batasan usia bagi orang yang hendak menikah. Hal ini juga diperkuat adanya kriteria khusus yang ditetapkan oleh Nabi bagi yang hendak menikah. Kriteria yang dimaksud adalah istițā'at al-bā'ah. Bā'ah secara literal bermakna jima' dan ada yang mengartikan biaya pernikahan. Dengan demikian, hadith ini secara implisit memberikan kompetensi khusus bagi mereka yang hendak melaksanakan perkawinan. Nabi SAW. juga memberikan jalur alternatif bagi orang yang tidak memenuhi kompetensi ini, yakni dengan berpuasa.

Lebih lanjut, jika mengamati pendapat ulama fikih, sebenarnya juga didapati pendapat adanya hukum sunnah bagi seorang ayah yang tidak terburu menikahkan anak perempuannya sampai ketika ia sudah mencapai usia bāligh, hal ini dilatarbelakangi kekhawatiran terjadinya hubungan yang tidak harmonis antara suami dan isteri. Bahkan secara tegas mereka melarang bagi seorang ayah menikahkan putrinya yang masih di bawah umur apabila tidak ada ketakutan hilangnya kemaslahatan sebab mengakhirkan perkawinan. ${ }^{26}$

Dari paparan di atas dapat diketahui bahwa sesungguhnya permasalahan pembatasan usia perkawinan merupakan permasalahan ijtihädiyyah yang dalam penggalian hukumnya harus selalu didasarkan pada 'illat (causa hukum) yang melatarbelakanginya serta mașlahah yang ingin dihasilkan.

2. Nilai Filsafat dalam Pembatasan Usia Perkawinan Dalam Kajian Filsafat Hukum Keluarga

a. Urgensi Filsafat dalam Aturan Pembatasan Usia Perkawinan

Agar dapat memahami secara mendasar dari nilai perkawinan khusunya masalah pengaturan pembatasan usia perkawinan sebagaimana yang telah diatur dalam Undangundang yang berlaku, perlu adanya pemahaman tentang hakekat dari pengaturan tersebut. Pengetahuan akan hakekat sebuah

\footnotetext{
${ }^{25}$ Muslim bin Hajjaj, Săhịh...., 148.

${ }^{26}$ Yahyā bin Sharaf al-Nawāwīi, Sharh Muslim, CD al-Maktabah al-Shāmilah, Vol. 9, 176.
} 
aturan dilakukan melalui unsur rasional manusia, guna mendapatkan pengetahuan secara mendasar dan radikal. Sehingga pengetahuan yang dihasilkan dapat menancap secara kokoh dan tidak mudah tergoyahkan.

Dalam mengetahui hakekat pengetahuan maka digunakan pemikiran filosofis melibatkan unsur ontologi (metafisik) dalam menggali hakekat pengaturan pembatasan usia perkawinan sebagai objek pembahasan.

Sebagaimana yang telah disebutkan dalam UUP Pasal 1 perkawinan adalah:

Ikatan lahir batin antara seorang pria dengan seorang wanita sebagai suami isteri dengan tujuan membentuk keluarga (rumah tangga) yang bahagia dan kekal berdasarkan Ketuhanan Yang Maha Esa. ${ }^{27}$

Selanjutnya dalam pasal 7 ayat (1) disebutkan:

Perkawinan hanya diizinkan jika pihak pria sudah mencapai umur 19 (sembilan belas) tahun dan pihak wanita sudah mencapai umur 16 (enam belas) tahun. ${ }^{28}$

Perkawinan dilaksanakan untuk membentuk ikatan kekeluargaan. Ikatan kekeluargaan dimaksudkan untuk memenuhi kebutuhan esensial manusia sebagai makhluk yang secara pribadi adalah sebagai seorang laki-laki dan seorang perempuan yang berhasrat memenuhi kebutuhan biologisnya. Disamping sebagai individu, manusia juga mempunyai relasi sosial yang dalam kesehariannya membutuhkan unsur ketenangan, ketertiban dan rasa saling peduli serta kasih sayang. Dalam pada itu sebagai seorang makhluk, manusia juga mempunyai hubungan dengan tuhannya sehingga pemenuhan unsur religius mutlak juga harus terpenuhi. Perkawinan dengan demikian, telah memenuhi seluruh unsur yang ada dalam diri manusia, baik sebagai individu, makhluk sosial maupun makluk berketuhanan. Dengan demikian, tinjauan ontologi tentang pengaturan pembatasan usia perkawinan menunjukkan bahwa pembatasan tersebut pada hakekat esensialnya merupakan sebentuk upaya hukum yang difungsikan guna memenuhi kebutuhan manusia sesuai kodratnya.

${ }^{27}$ Undang-Undang Nomor 1 Tahun 1974 Tentang Perkawinan Pasal 1.

${ }^{28}$ Undang-Undang Nomor 1 Tahun 1974 Tentang Perkawinan Pasal 7 ayat (1). 
Untuk memahami hakekat kebenaran yang telah dicapai oleh rasional tentang aturan pembatasan usia perkawinan, aspek epistemologi merupakan upaya filosofis untuk mengungkapnya. Setidaknya terdapat tiga teori tentang kebenaran sebagaimana yang dipedomi oleh para filosof, yakni (1) Teori Kebenaran Koherensi yang mendasarkan pada kriteria tentang konsistensi suatu argumen; (2) Teori Kebenaran Korespondensi yang mendasarkan pada kriteria tentang kesesuaian antara materi yang dikandung oleh suatu pernyataan tersebut; dan (3) Teori Kebenaran Pragmatis yang mendasarkan diri pada kegunaan, efisiensi dan kepuasan. ${ }^{29}$ Dari ketiga teori kebenaran, keberadaan aturan pembatasan usia perkawinan mendapatkan sisi kebenarannya. Pertama, secara koherensi, aturan tersebut telah bersesuaian dengan tujuan dasar perkawinan untuk membentuk keluarga yang bahagia dan kekal yang hanya akan terwujud jika para pelakuknya telah dapat mengetahui dan melaksanakan hak dan kewajibannya masing-masing. Secara korespondensi, aturan tentang pembatasan usia perkawinan telah benar-benar dilaksanakan sesuai aturan oleh para aparatur negara yang berwenang dan telah dilakukan secara nyata oleh masyarakat sebagai objek yang diatur. Sedangkan secara pragmatis, aturan tentang pembatasan usia perkawinan telah berguna untuk menekan angka perceraian akibat tidak harmonisnya keluarga, kekerasan rumah tangga, menekan resiko angka kematian akibat kurang siapnya kematangan secara biologis, serta menekan maraknya perkawinan anak-anak usia dini.

Masih dalam pembahasan yang sama, aspek aksiologi berupaya mengetahui hakekat esensial nilai yang terdapat dalam aturan tentang aturan pembatasan usia perkawinan. Nilai yang dimaksud di sini berkaitan dengan baik dan buruk, etika dan moral serta manfaat yang terkandung dalam aturan tersebut. Diungkapkan bahwa di antara dampak dari tidak adanya pembatasan usia perkawinan dapat berakibat pada bahaya kesehatan dan bahaya sosial.

Di antara bahaya kesehatan adalah resiko melahirkan bayi prematur dan kerusakan organ tubuh ibu yang melahirkan.

${ }^{29}$ Abu Yasid, Aspek-aspek Penelitian Hukum: Hukum Islam Hukum-Hukum Barat (Yogyakarta: Pustaka Pelajar, 2010), 92. 
Sedangkan bahaya sosial yang timbul adalah meningkatnya angka kehamilan yang tidak diinginkan, aborsi, perdagangan manusia, jumlah anak yang terlantar, serta meningkatnya angka perceraian dan pengangguran, meningkatnya penindasan terhadap perempuan dan tentunya meningkatnya angka perceraian. ${ }^{30}$ Dengan demikian, jika bahaya-bahaya sebagai akibat praktik perkawinan yang tidak memenuhi kriteria usia tersebut telah dapat berkurang, maka menunjukkan dengan jelas adanya nilai manfaat yang terkandung dalam aturan pembatasan usia perkawinan.

\section{b. Pembatasan Usia Perkawinan Menurut Filsafat Hukum Keluarga Islam}

Filsafat hukum keluarga Islam bisa dikatakan sebagai anak sulung dari filsafat hukum Islam. Dalam kajian filsafat hukum Islam, para ahli membagi menjadi dua macam filsafat, pertama adalah filsafat tashri' dan filsafat shari'ah. Filsafat tashrí' menekankan pembahasan atas dāim al-aḥkām (dasar-dasar hukum Islam), mabādi al-ạ̣kām (prinsip-prinsip hukum Islam), uṣūl al-ạ̣kām (pokok-pokok hukum Islam), maqāsid al-aḥkām (tujuan-tujuan hukum Islam) serta qawāid al-aḥkām (kaidahkaidah hukum Islam). Sementara filsafat shari'ah berbicara tentang asrār al-ahkām (rahasia-rahasia hukum Islam), khașāiș al-ahkām (ciri khas hukum Islam), mahāsin al-ahkām (keutamaan-keutamaan hukum islam) dan tawābi' al-ạ̣kām (karakteristik hukum Islam). Permasalahan pembatasan usia perkawinan jika dikaitkan dengan filsafat tashri ' maka domain kajian berkait dengan maqāsid al-aḥkām (tujuan-tujuan hukum Islam).

Tujuan utama shari' $a h$ adalah mewujudkan kebaikan kepada manusia dalam urusan mereka, baik di dunia maupun di akhirat. Secara umum shari'ah dalam semua bagiannya hendak mengamankan kebaikan manusia baik berupa perintah untuk mengamankan kebaikan atau larangan untuk menghindari kerusakan dan kejahatan. ${ }^{31}$

\footnotetext{
${ }^{30}$ M. Alfatih Suryadilaga, "Efek Pernikahan Dini", Musāawa, Vol. 8, No. 2 (Juli, 2009), 256.

${ }^{31}$ Mohammad Hashim Kamali, Membumikan Syariah: Pergulatan Mangaktualkan Islam, terj. Miki Salman (Jakarta: Mizan, 2013), 43.
} 
Selain dengan memanfaatkan ajaran Al-Qur'an, al-Sunnah serta ijmā' dalam mewujudkan kemaslahatan yang dimaksud, dalam hukum Islam penggunaan rasio sebagai alat interpretasi tidak dapat dipungkiri. Penggunaan rasio dalam memahami nașs adalah standar pemahaman yang benar dan itu sama halnya mengamal-kan nașs, bukan mengamalkan rasio, demikian ungkap al-Sarkhași sebagaimana dikutip Ahmad Imam Mawardi. ${ }^{32}$ Penggunaan rasio melalui qiyas berikut varian baru seperti istiṣhāab, istiḥsān, istịslạh dan al-maṣlaḥah al-mursalah, betapa pun terdapat perbedaan pendapat terkait otoritasnya sebagai metodologi hukum, nyatanya tetap cukup efektif dalam mengatasi permaslahan-permasalahan hukum wäqi'iyyah.

Rasionalisasi dan interpretasi hukum yang telah dilakukan merupakan upaya menyelaraskan tujuan pensyariatan dan realita yang ada. Upaya ini penting dilakukan, sebab sebagaimana yang dikatan oleh al-Shahrastāni sebagaimana diungkapkan oleh Abd. Salam Arief bahwa:

Teks-teks naș itu terbatas sedangkan problematika hukum yang memerlukan solusi tidak terbatas, oleh karena itu diperlukan ijtihad untuk menginterpertasi naș yang terbatas itu agar berbagai masalah yang tidak dikemukakan secara ekplisit dalam naș dapat dicari pemecahannya. ${ }^{33}$

Aspek kemaslahatan hendaknya dijadikan sebagai ruh dan pertimbangan utama yang dilakukan oleh para ahli hukum dalam melakukan ijtihad. Sebab inti dari keseluruhan shari'ah mengarah hanya kepada dua hal, yakni mendatangkan kemashlahatan dan menolak kerusakan. Penentuan terhadap kemashlahatan dan kerusakan dapat diketahui dengan akal, begitu pula terhadap sebagian besar urusan shari'ah. ${ }^{34}$ Dalam perkembangannya, jika terjadi kontradiksi antara kemaslahatan dan kerusakan, maka yang diunggulkan untuk dilaksanakan adalah menolak kerusakan. Terdapat satu kaidah terkenal:

\footnotetext{
${ }^{32}$ Ahmad Imam Mawardi, Qiyās dan Istiḥsān Dalam Rasionalitas Ușūl al-Sarkhasī, Islamica, Vol. 7, No. 1 (September, 2012), 95.

33 Abd. Salam Arief, Pembaharuan Pemikiran Hukum Islam Antara Fakta dan Realita (Yogyakarta: Lesfi, 2003), 15.

34 'Izzuddin bin 'Abd al-Salām, Qawāid al-Aḥkām fī Maṣālị̣ al-Anām (Beirut: Dār al-Kutub al-'Ilmiyah, 1999), 8.
} 
Menolak kerusakan lebih diprioritaskan daripada mendatangkan kebaikan. ${ }^{35}$

Masalah perkawinan, dalam hukum Islam tidak didapati adanya pembatasan usia perkawinan. Ketiadaan batasan usia perkawinan mengandung beberapa manfaat yang di antaranya dapat segera dilangsungkannya perkawinan di antara seorang pria dan seorang wanita sehingga dapat segera menjalankan sunnah Rasul berupa perkawinan, selain juga mempererat tali persaudaraan di antara dua keluarga. Bahkan tradisi perkawinan semacam ini juga pernah dicontohkan oleh Rasul dan para sahabatnya.

Namun demikian, melihat ekses-ekses negatif yang muncul akibat tiadanya batasan usia perkawinan, maka dianggap penting adanya pembatasan usia tersebut. Pembatasaan usia perkawinan tidak bermaksud untuk menghambat seseorang melakukan perkawinan, namun lebih bertujuan untuk menghindarkan diri dari bahaya dan kerusakan yang ditimbulkan.

Sekalipun adanya pembatasan usia perkawinan dalam UUP secara lahiriah tampak berlawanan dengan ketentuan hukum fikih, namun secara filosofis tidaklah demikian, sebab telah bersesuaian dengan ruh dan tujuan dari fikih itu sendiri, yakni terpenuhinya asas kemashlahatan dengan berupaya menghilangkan kerusakan-kerusakan.

\section{Penutup}

Pengaturan pembatasan usia perkawinan sebagaimana diatur dalam Undang-undang Nomor 1 Tahun 1974 Pasal 7 ayat (1) dilakukan sebagai upaya pengaturan demi terwujudnya cita-cita perkawinan sebagaimana termaktub dalam UUP Pasal 1. Pembatasan usia perkawinan masih membuka peluang adanya pengecualian sebagaimana diatur dalam UUP Pasal 7 ayat (2).

Nilai filosofis dari penyusunan aturan pembatasan usia perkawinan dalam UUP dapat ditinjau melalui aspek ontologis, epistemologis dan aksiologis. Menurut filsafat hukum keluarga, pembatasan usia perkawinan terkatagori sebagai filsafat tashri, terkhusus masalah maqāsid al-ạ̣kām (tujuan-tujuan hukum Islam) berupa pemenuhan kemashlahatan dan menolak kerusakan.

${ }^{35}$ Muḥammad 'Azzām, Al-Qawāid al-Fiqhiyyah (Kairo: Dār al-Ḥadith, 2005), 145. 
Memandang hukum keluarga khususnya berkaitan dengan Undang-Undang Nomor 1 Tahun 1974 hendaknya tidak hanya terbatas sebagai realitas belaka dari hukum atau ilmu hukum, sehingga hanya didekati melalui aspek normatif-yuridis saja. Pendekatan secara filosofis dan sisologis juga harus dilakukan oleh mereka yang berkonsentrasi dalam kajian hukum keluarga. Sebab aturan hukum positif akan efektif berlaku bila memenuhi tiga syarat. Ketiga syarat itu adalah berupa keabsahan secara sosiologis , absah secara yuridis, dan absah secara filosofis. 


\section{Daftar Pustaka}

'Azzām, Muḥammad. Al-Qawāid al-Fiqhiyyah. Kairo: Dār al-Ḥadith, 2005.

'Ubaidi (al), Hammādi. Al-Shatibī wa Maqāṣid al-Sharīah. Beirut: Dār Qutaybah, 1992.

Arief, Abd. Salam. Pembaharuan Pemikiran Hukum Islam Antara Fakta dan Realita. Yogyakarta: Lesfi, 2003.

Buṭi (al), Muhammad Ramaḍān. Dawābit al-Maṣlahah. Beirut: Muassasat al-Risālah, 2001.

Hajjaj, Muslim b.. Sạhịh Muslim. Beirut: Dār al-Kutub al-'Ilmiyah, 2006.

Hazm, Ibnu. Al-Muhalla. CD al-Maktabah al-Shāmilah.

Kamali, Mohammad Hashim. Membumikan Syariah: Pergulatan Mangaktualkan Islam, terj. Miki Salman. Jakarta: Mizan, 2013.

Mawardi, Ahmad Imam. Qiyās dan Istiḥsān Dalam Rasionalitas Uṣūl al-Sarakhsī, Islamica, Vol. 7, No. 1, September, 2012.

Munti, Ratna Batara dan Hindun Anisah. Posisi Perempuan Dalam Hukum Islam di Indonesia. Jakarta: LBH-APIK, 2005.

Nawawī (al), Yahyā b. Sharaf. Sharh Muslim. CD al-Maktabah alShāmilah

Nuruddin, Amiur dan Azhari Akamal Taringan. Hukum Perdata Islam di Indonesia. Jakarta: Prenada Media, 2004.

Qudamah, Ibnu. Al-Mughnī. Beirut: Dār al-Fikr, 1984

Sābiq, Sayyid. Fiqh al-Sunnah. Beirut: Dār al-Fikr, 1990.

Salām (al), 'Izzuddīn b. 'Abd. Qawāid al-Aḥkām fị Mașālị̣ al-Anām. Beirut: Dār al-Kutub al-'Ilmiyah, 1999.

Suryadilaga, M. Alfatih. "Efek Pernikahan Dini”, Musāwa, Vol. 8, No. 2, Juli, 2009.

Syarifuddin, Amir. Hukum Perkawinan Islam di Indonesia. Jakarta: Kencana, 2007.

Syathi', 'Aisyah Binti. Nisā' al-Nabī, terj. Bandung: Pustaka Hidayah, 2004.

Yanggo, Huzaimah Tahido. Masail Fiqhiyah: Kajian Hukum Islam Kontemporer. Bandung: Angkasa, 2005.

Yasid, Abu. Aspek-aspek Penelitian Hukum: Hukum Islam HukumHukum Barat. Yogyakarta: Pustaka Pelajar, 2010. 